Urban design, public space and the dynamics of creative milieus: a photographic approach to Bairro Alto (Lisboa), Gracia (Barcelona) and Vila Madalena (São Paulo)

Pedro Costa Ricardo Lopes

2012

WP n. ${ }^{\circ} 2012 / 18$ 


\section{DINAMIP'CET}

CENTRO DE ESTUDOS SOBRE A MUDANCCA

SOCIOECONOMICA E O TERAITÓRIC

ISCTE-IUL

Urban design, public space and the dynamics of creative milieus: a photographic approach to Bairro Alto (Lisboa), Gracia (Barcelona) and Vila Madalena (São Paulo)

Pedro Costa ${ }^{1}$ Ricardo Lopes ${ }^{2}$ WP n. ${ }^{\circ} 2012 / 18$

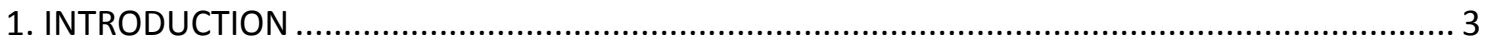

2. THE GENERAL FRAMEWORK OF THE RESEARCH: THE CREATCITY PROJECT ............................ 4

3. A PHOTOGRAPHIC APPROACH TO THE THREE DISTRICTS: THE METHODOLOGICAL APPROACH. 6

4. PUBLIC SPACE APPROPRIATION AND CREATIVE DYNAMICS IN THE 3 CASES . .8

6. CONCLUDING NOTE.. 24

REFERENCES 27

\footnotetext{
${ }^{1}$ DINÂMIA'CET - IUL and ISCTE - Lisbon University Institute. E-mail pedro.costa@iscte.pt.

2 DINÂMIA'CET - IUL. E-mail ricardovenanciolopes@gmail.com.
} 


\title{
Urban design, public space and the dynamics of creative milieus: a photographic approach to Bairro Alto (Lisboa), Gracia (Barcelona) and Vila Madalena (São Paulo)
}

\begin{abstract}
${ }^{3}$ :
Drawing on some results of a broader research project, this paper aims to discuss the relation between urban design and the creative dynamics in cultural districts. Appropriation and production of public spaces in three "creative quarters" (Bairro Alto, Lisbon; La Gracia, Barcelona; Vila Madalena, São Paulo) are analyzed. The specific conditions and ambiances which seem to be determinant to embed sustainable creative processes in these areas are studied, aiming to explain the development of "creative milieus" and their relation with the urban socioeconomic and morphological dimensions.

The main conceptual and empirical framework of the project is briefly presented, in order to sum up the main key-issues on the relation between urban form and creative clustering. Then, the methodological and empirical approach followed in this particular part of our work is described. The analysis and discussion of more than one thousand images allowed characterizing each district on 15 analytical dimensions, covering material aspects, human appropriation and livability and the symbolic dimensions of it.

Departing from a discussion on the boundaries of public spaces and their relevance for creative dynamics (through the conviviality and sociability they promote), it is argued that urban design characteristics and specific place morphologies are determinant for the attractiveness of creative activities and for the appropriation of these areas. Their role on the sustainability of each of these districts, as they become challenged as "vibrant" and "creative" centers in their cities, is also discussed. Finally some concluding policy guidelines are drawn out from the analysis.
\end{abstract}

\section{Keywords:}

Creative milieus; Creativity; Cultural quarters; Public spaces; Photography.

\footnotetext{
${ }^{3}$ This text was presented as a paper to the 26th Annual Congress of AESOP (Association of European Schools of Planning), in Ankara, Turkey, July $10^{\text {th }}-15^{\text {th }}, 2012$. The authors thank the feedback and comments of the organizers and participants on that session, and the contributions on paper referee.
} 


\section{INTRODUCTION}

This paper aims to discuss the relation between urban design and the creative dynamics verified in cultural districts. In recent years multiple territories have stood out as 'creative milieus' as they offer a specific atmosphere or certain conditions required to embed and develop sustainable creative processes in cultural activities (see Camagni et al. 2004; Cooke and Lazzeretti 2007; Costa 2007; Costa et al, 2011; or in a wider perspective, O'Connor and Wynne 1996; Scott 2000). This "creative milieus" configure very distinct situations and usually are based on specific governance mechanisms that play a key part in most of those success cases. In this paper we focus specifically on the "cultural districts" or "cultural quarters" case (cf. Costa et al, 2008).

Our analysis draws upon some of the results of the research project "Creatcity - A governance culture for the creative city: urban vitality and international networks", which focused on the understanding of the spatial conditions that support creative clusters and the vitality and sustainability of "creative milieus". An analysis of the appropriation and production of public spaces in the "creative quarters" is made, departing from 3 case studies of creativityled territorial systems in Lisbon, Barcelona and São Paulo metropolitan areas. Through a photographical approach that complements other methodological approaches to these experiences, and departing from the study of the specific conditions and ambiances which seem to be determinant to embed sustainable creative processes in those areas, we aim to explain the development of these "creative milieus" and their relation with the urban socioeconomic and morphological dimensions. The perspective is centered on the governance and the sustainability of these territorial dynamics, at the light of the research framework pursued in that project.

The general conceptual and empirical framework of the project is briefly presented on section 2 and the methodological approach that was followed is generally described on section 3. We focus on 3 of the 10 case studies analyzed, one cultural quarter in each city (Bairro Alto, Lisbon; La Gracia, Barcelona; and Vila Madalena, São Paulo). The main characteristics and dynamics of each of these territorial systems are discussed, evidencing how urban morphology, features of "physical" place and potential for public space appropriation are determinant to the vibrancy and liveliness of these areas. Departing from a discussion on the boundaries of public spaces and their relevance for the creative dynamics (through the conviviality and sociability they promote), on section 4 , we discuss how the characteristics of urban design, specific place morphologies and typologies are determinant for the attractiveness of creative activities and for the appropriation of these areas. Consequently, on section 5, we debate their importance at the light of the main challenges to the sustainability of each of these areas as "vital" and "creative" 
centers in their cities. Finally some concluding policy-making generic guidelines are drawn out from the analysis.

\section{THE GENERAL FRAMEWORK OF THE RESEARCH: THE CREATCITY PROJECT}

The aim of the 'Creatcity' project ('Creatcity: A Governance Culture for the Creative City: Urban Vitality and International Networks'), funded by the Portuguese Science and Technology Foundation (FCT/MCTES), was to discuss territorially based creative dynamics and their governance mechanisms in diverse urban contexts. Drawing on the 'creative cities' debates, it sought to further knowledge and to build strategic action guidelines on governance mechanisms and dynamics that promote and embed urban vitality, creativity and competitiveness. It combined a conceptual and empirical component, focusing on the cities of Lisbon (Portugal), Barcelona (Spain) and São Paulo (Brazil), where ten empirical case studies were selected for indepth analysis.

The project was based on a transversal analysis of creativity in the three cities with the aim of drawing strategic policy-acting guidelines for the Lisbon metropolitan area. It encompassed several thematic dimensions: (a) systematizing contemporary economic restructuring and territorial challenges in each metropolitan area; (b) mapping their creative activities and resources; (c) analyzing the relation of these creative dynamics with material space, urban morphology and social appropriation of urban areas; and (d) examining local policy actions for internationalization. ${ }^{4}$

In addition to specific case studies, other methodologies were applied (desk research, both empirical and conceptual, etc.). Complementary empirical analyses were made in the three cities (data series, statistical analysis, etc.) as well as extra fieldwork in some case studies (urban, functional and morphological analyses, photographic survey, image examination, etc.). In articulation to all these, the main core methodological framework combined two steps:

(i) A set of exploratory interviews: twenty-two exploratory interviews (ten in Lisbon, six in Barcelona, six in São Paulo) with local/regional/central government authorities in different fields from urban, cultural and economic policy areas; with experts in consultancy and the academic world; and with some prominent creative/cultural institutions (cf. Seixas and Costa, 2010 for details).

4 For more information see http://creatcity.dinamia.iscte.pt. 
(ii) A set of case studies: ten case studies in the three metropolises (using nearly seventy in-depth interviews and other methodologies), i.e. Bairro Alto, Almada, Alcântara and Martim Moniz areas in Lisbon; Gracia district, 22@ urban renewal operation, and Palo Alto Association in Barcelona; Vila Madalena district, the event São Paulo Fashion Week event, and the institution SESC (Commerce Social Services) in São Paulo (cf. Costa 2012, 2013 for details).

A comparative approach was taken in just three of these case studies: Bairro Alto in Lisbon, Gracia in Barcelona and Vila Madalena in São Paulo, all of which are 'conventional' creative districts or cultural quarters. Despite slight differences and nuances, and quite diverse historical and institutional backgrounds and urban characteristics, they share an analogous situation: 'creative' segments of the population (artists, bohemians, cultural activities, nightlife and other conviviality and sociability nodes) were going through a process of 'taking over' traditional residential areas in the three cases. Moreover, they are now all experiencing growing gentrification processes and a sort of shift from production to consumption, or from traditional cultural activities to more commodified market based aesthetic-driven activities (with the progressive replacement of performing and visual arts with design shops and nightlife, for instance). Like many other cultural and creative districts all over the world, there are also strong use conflicts between residents and users, night-time and daytime activities, traditional and new residents, traditional and new activities, etc. These conflicts, most of them expressed in daily life and on the public space appropriation by their diverse users, play an essential role in the governance of these districts and on their sustainability challenges (see Costa et al, 2010; Costa 2013, 2012b for details).

A comprehensive photographical approach to those public spaces and those dynamics (assumed as central in the empirical work conducted in each of these quarters) is the departing point for the specific analysis presented in this paper. The analysis and discussion of more than one thousand images collected in the 3 case studies allowed characterizing each district through 15 different analytical dimensions, covering material aspects of those spaces, their human appropriation and livability and the symbolic dimensions of this appropriation. That is what we will go through in the subsequent sections. 


\section{A PHOTOGRAPHIC APPROACH TO THE THREE DISTRICTS: THE METHODOLOGICAL APPROACH}

There are several ways to analyse the public space, and many were used by us along this Creaticity project. This photographic approach is part of the analyses conducted in these 3 districts, which aimed to compare the different realities founded in each of them, following a set of pre-systematized criteria.

Through a wide range of images collected in a photographic survey, realized alongside other surveys and other kinds of approaches aimed at the systematic collection of qualitative and quantitative empirical evidence on the same locations, we sought to understand the creative dynamics and the appropriation of public space concerning 15 thematic issues, grouped around a restricted set of broader dimensions of analysis.

The photographic survey obeyed a set of rules and presupposed certain objectives for the fullest possible coverage of the dynamics verified on these neighborhoods. For each quarter, six streets or squares, with diverse uses and users, were selected. We tried to cover with that selection the different dynamics pre-identified in the area. Throughout two specific days of the week (Thursday and Friday), and on three different moments (morning, afternoon and evening), photos were made in those six places pre-chosen in each quarter, by five elements of the research team involved in this task. As aim of this specific work it was to make a photographic survey assuming the personal interpretation that each elements of the team brought about that public space.

In any perspective, we would need to learn how the appropriation of the public spaces of the quarter is done and how this affects the social, economic and cultural practices that take place in them. For such, bearing in mind the "documental" side about the reality that each one would want to convey, it was necessary to identify a group of outlining aspects of each one of these quarters and their everyday life, from the diversity of its users and regulars (in its various times and spaces) to the multiplicity of existing spaces (morphology, physical characteristics, materials, urban furniture, etc.); from the plurality of uses, experiences and appropriations possible to recognize in there (forms of using, coding, etc.), to the conflicts of use and the problems associated to occurring externalities; or also to the variety of signs and symbols, direct or indirect, which can be associated to existing social practices in those spaces.

On the basis of a conceptual framework that looked to these spaces in a triple perspective (crossing morphology, forms of appropriation and governance forms), we built a set of variables that were taken over as key to the analysis of the urban vitality of these areas, aiming to cover aspects as diverse as the social and functional diversity, accessibilities, identities and social capital, the "quality" of place or the local creativity.

Within this framework, we defined three broad dimensions for analyzing public spaces: 
Urban design, public space and the dynamics of creative milieus:

a photographic approach to Bairro Alto (Lisboa), Gracia (Barcelona) and Vila Madalena (São Paulo)

A) The material space: the way natural and built space conditions the activities and functions that take place on it;

B) The living of the spaces: the way it is experienced and appropriated by its diverse users (residents, workers, tourists, etc.) and the conflicts that this engenders;

C) The symbolic dimension: the way it is perceived and represented and how it conditions and multiplies its appropriations (and the symbolic and cultural accessibility into it).

These three major dimensions were decomposed into themes, from which the photographic collection was conducted and the scan was completed, using the images. We opted to add a fourth dimension of analysis to those 3 , focalizing on cross-cutting themes, and embodying the very dynamics of these quarters in their diverse times and spaces, that is, their multiple (but coincident) temporalities and spatialities.

Figure 1: Dimensions and themes for photographic recollection

\begin{tabular}{|c|c|c|}
\hline$N^{0}$ & Dimension & Theme \\
\hline 1 & \multirow[t]{4}{*}{ A-The material space } & The materiality (morphology, volumes, topography,...) \\
\hline 2 & & The urban facilities (urban equipment, public furniture) \\
\hline 3 & & The green spaces \\
\hline 4 & & The "light" / the luminosity / the "ambiances" \\
\hline 5 & \multirow[t]{6}{*}{ B - The living of the space } & The functional diversity in the neighborhood \\
\hline 6 & & The social diversity in the neighborhood \\
\hline 7 & & To "dwell" the neighborhood \\
\hline 8 & & To "circulate" in the neighborhood \\
\hline 9 & & To "live" the neighborhood \\
\hline 10 & & The use conflicts \\
\hline 11 & \multirow[t]{3}{*}{ C-The symbolic dimension } & The signs and symbols \\
\hline 12 & & The identity characteristics of each quarter \\
\hline 13 & & The spaces of inclusion and exclusion (symbolic/cultural) \\
\hline 14 & \multirow[t]{2}{*}{ "Transversal" dimensions } & The different times / rhythms of the quarter \\
\hline 15 & & The different "spaces" of the quarter \\
\hline
\end{tabular}




\section{PUBLIC SPACE APPROPRIATION AND CREATIVE DYNAMICS IN THE 3 CASES}

Public space is an arena for several appropriations, place of exchanges, meetings and sociability, one of theaters of everyday life. It is traditionally characterized for being a collective place that doesn't belong to anyone and belongs to everyone, usually managed by a public entity that has the duty to administer it and the conflicts that take place in there. If in beginnings, from an urban-morphological perspective, they could be characterized by being only the leftovers spaces between the buildings, where one could circulate, or the market squares at the city gates, where trade took place, rapidly and encompassing evolving civilization they assume another importance in cities, becoming privileged places for power demonstrations, for worship, for trade, for traffic or for conviviality and social representation.

Thus, naturally, this basic concept which could be characterized as a space of inclusion and citizenship, where all citizens could access, quickly is diluted by the hierarchical and social construction that takes place in all societies, and that is being complexifyied by evolution and technological progress. However, "the notion that the public space should be an equal space, not exclusionary, and of free access to all individuals is a central idea of the current theoretical debate in the city" (Balula, 2010, pp. 44).

In effect, those are central issues on contemporary discussions on public spaces and public sphere in the city. Public space is not as easy concept to operationalize, particularly on present-day societies. In the framework of this research we discussed and assumed a concept that is embodying the crossing of three different layers (i) the public/private or collective/individual property and management of those spaces; (ii) the public/private interests around their development and use (e.g., public/private goods); (iii) and the collective/individual appropriation of them (e.g., on their access). The crossing of the several possibilities in each of these layers gives us the wide diversity of situation that characterizes contemporary polemic on public spaces definition and their boundaries (e.g. public streets in private urban resorts; public spaces in private-managed shopping malls; private management of public facilities, and so on). It is not our intention to in-deep this debate here (cf. Costa, 2013 on that), but just to frame briefly how we got an operative tool to analyze these spaces in our photographic approach.

The Italian architect Giambattista Nolli was the first to introduce in a plant from one city the question of the limits and boundaries of the public space, when mapping the city of Rome, in 1748, has represented the urban spaces of public sphere of Rome in the same way that the conventional public spaces ${ }^{5}$ (e.g. church interiors). That arose naturally the question about

\footnotetext{
5 Assuming "conventional public space" as places where anyone could access without any kind of restriction, as city streets or squares.
}

DINÂMIA'CET - IUL, Centro de Estudos sobre a Mudança Socioeconómica e o Território 
where begins and ends the public space, which is a debate that continues until today, as seen above. However, assuming that the public space is a diffuse place, with rather uncertain and changing boundaries, and expressed in quite undefined spaces within the core of increasingly "privatized cities", it interested to us in this work to photograph and analyze the appropriations that occur in spaces in the urban public sphere, that, regardless of belonging or being managed by "public" or "private" entities, could be freely or easily appropriated by the population. Also, it interested to us to assume the public space appropriations which have a direct influence on "conventional" public space, by their own nature, such as ground floor business, car's parkings, gardens or cultural facilities, which regardless to need an invitation, authorization or economic transaction to be used, can be appropriated essentially in a "democratic" way. If we just call "public space" to places which could be appropriate by all, without any schedule, economic or social restriction, we could call urban spaces belonging to the public sphere to those others. Thus, we felt the need to extend our research to those "urban spaces of public sphere" because increasingly we see a relative decline of the importance of "traditional public spaces" in the life of society. Furthermore, these places affect directly the vitality of public spaces adjacent to it, functioning as its extension, where boundaries and borders disappear. In the presence of this decline of importance of archaic public space, other seem to arise, as shopping centers or other, that simulating the appearance of traditional public spaces, offering a controlled environment, and easy access by car, give the possibility to find a large agglomeration of services, differently from what we have in the city. Despite this more mediatized panorama on many contemporary cities, it continues to coexist with areas that due to their characteristics and peculiarities keep particularly vital, and the case studies in our analysis area good example of that.

In effect, cities are regulated by segregation systems. Through various ways it is possible to mediate and control the modes of city appropriation, at diverse scales. That always happened in such a way, as Balula describes in relation to social segregation of Greek Acropolis, according to the social status of the population, or in numerous other conviviality spaces throughout history: "As the Greek polis, many of the public spaces of the past - as Roman Forum, the medieval market, the monumental squares and boulevards of the Renaissance, the bohemian cafes, or the salons of Enlightenment - were in fact places relatively few inclusive, in the modern sense of the term" (Balula: 2010, 44).

Creative dynamics often take place and develop in this threshold ground, in the diffuse field of the places of conviviality, in the urban spaces of public sphere. Multifunctional places in the city, dense, and composed by several layers of segregation, which are being permanently decodified and appropriated by different audiences, which face these areas as great showcases for 
visibility, away from traditional circuits. The urban creative milieus and particularly the cultural districts are good examples of this.

Characterized by being places of the city where there is more freedom for speech and for expression and creation, with fewer levels of social control and often greater tolerance to informality, consequently, they left more opportunity for space appropriation, and mostly for diversity and heterogeneity of appropriations. This makes these urban spaces of public sphere areas of major importance for a sector like cultural activities, where not only is important to think about places of production (which in most cases does not even occur in these areas, with the exception of fields such as street art or urban artistic intervention in visual and performing arts , that have ample importance and visibility in these territories), but also as fundamental arenas for developing conviviality nodes, mediation activities and to occur affirmation within artistic circles. In parallel, but also for all these, they easily assume their liminal character, being particularly attractive to transgression, experimentation and all kinds of social mobility (cf. Arantes, 1997).

In these spaces the symbolical sphere plays an important role and its importance is fundamental for understanding the existing fragmentation. The ones who come to these spaces are looking for a constructed image (of the place, of themselves, of their groups, of what they want to be), they are looking for symbolism. These are particular places for representation, for the assumption of specific lifestyles and ways of life (Cf O'Connor and Wynne, 1996) and therefore, the concept of urban theatricality is sharp in these territories, and along with the liminality processes, we can watch to a natural segregation of practices and people in the different spaces (or even in the same places, each with several codified layers of representations, differently de-codified by their different audiences and users). Often, this process is based on auto-segregation, but sometimes it naturally also involves conflict between the diverse potential users and power relations that take place and develop within that system or with external regulation.

It is therefore usual to watch, in all the three cases studies, to a constant appropriation of urban spaces belonging to the public sphere, as uses are evolving and changing through time and users and audiences also evolve, adapting to the new ways how these spaces are being appropriated. This mix and this continuous social and cultural negotiation leads naturally to permanent (but evolving) use conflicts, that are particularly notices in each of this cultural districts. When in the same area of the city we can watch different times and rhythms throughout the day, or even co-existing parallel dynamics in the same moment at the same place, that would be perfectly natural. But these dynamics existing in these areas is an intrinsic 
part of its vitality, and the changes and tensions in the public users and in the uses of those areas are one key-issue for the neighborhoods to keep always its life and its liveliness.

A transversal pattern in all these districts is accentuated by the calm rhythm met by the mornings in contrast with the rush that these spaces stage by nightfall, when the local traditional commerce start to close its doors and in counterpoint come to life the locations of conviviality and bohemia such as restaurants and cafes, and the "alternative" or "fashion" shops that are increasingly replacing former areas of artistic production or commerce of proximity. This panorama is a well known part of the particular processes of gentrification occurring in those kinds of districts, all over the world, and is probably natural in the evolution of cities and their revitalization processes. These territorial systems evolve, with their changing dynamics, the evolution in the dominant uses and the replacing of their regular users, and in some cases it may put in cause these dynamics as we knew it (Costa, 2009, 2012). As we defended somewhere else (Costa, 2013), if this situation may not be problematic when there are other areas in the city with the same dynamic as in the Barcelona and in São Paulo cases, it may be more worrying in terms of the sustainability of the "creative system" in the Lisbon case, when we do not identify another area with the same dimension, density and heterogeneity of relations and other characteristics essential to maintain this agglomeration of creative sector's activities.

In conclusion, we noticed in this section that several factors influence how urban spaces of public sphere are appropriated and shape the social relations that take place on it. The morphology and the urban design of these territories have also a particular importance in the sustainability of these dynamics and in the vitalization of these areas as cultural districts and attractive arenas for cultural production consumption and mediation processes. We will explore that in the next section, but before that, we suggest a digression through these spaces in our 3 case studies, by observing the selection of images presented in Figures 2, 3 and 4, which give us some brief insights on the reality of each of those experiences. That is with that ground that the discussion of the next section will be held. 
Urban design, public space and the dynamics of creative milieus:

a photographic approach to Bairro Alto (Lisboa), Gracia (Barcelona) and Vila Madalena (São Paulo)

Figure 2: Photographic approach to Bairro Alto (I)

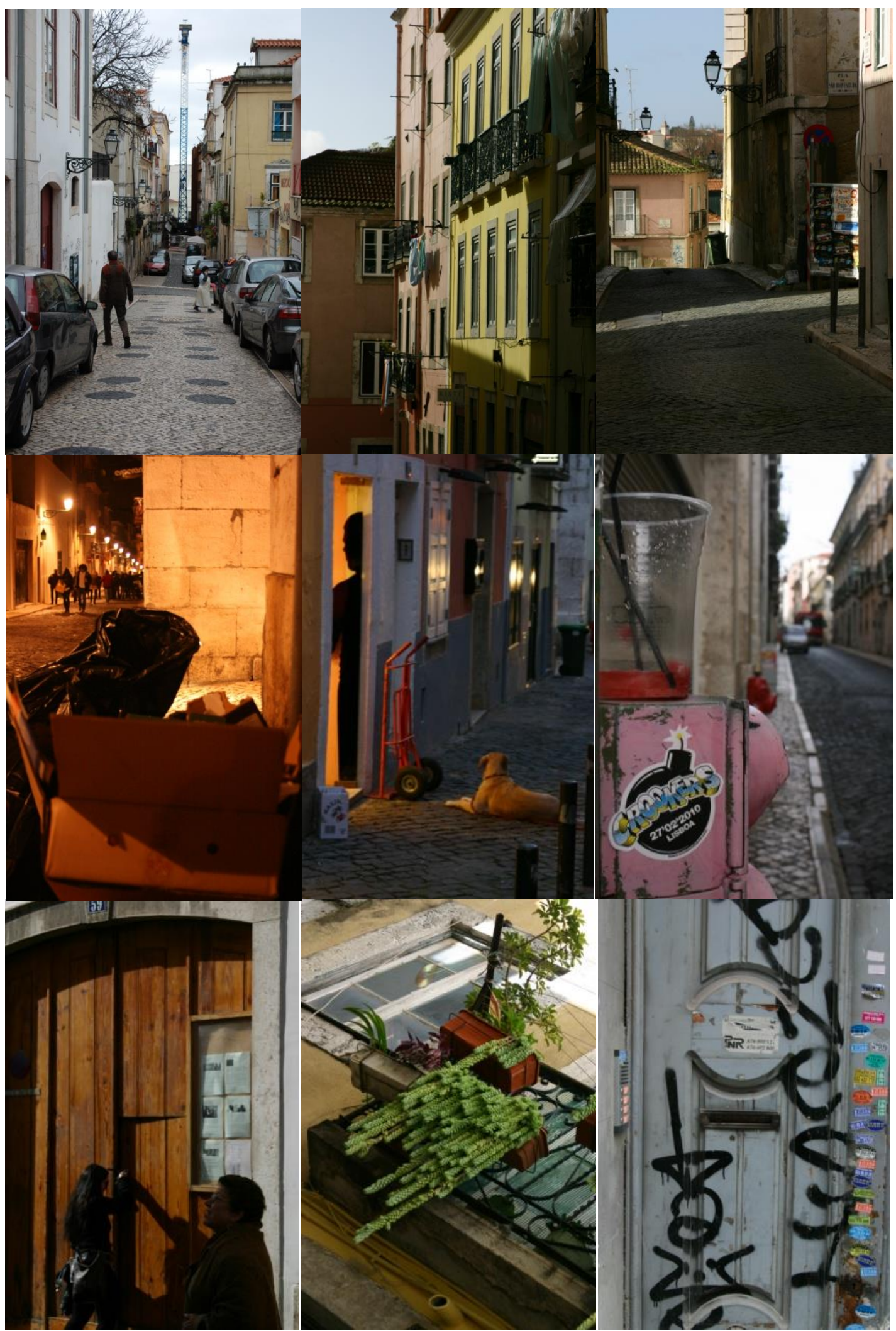


Urban design, public space and the dynamics of creative milieus:

a photographic approach to Bairro Alto (Lisboa), Gracia (Barcelona) and Vila Madalena (São Paulo)

Figure 2: Photographic approach to Bairro Alto (II)
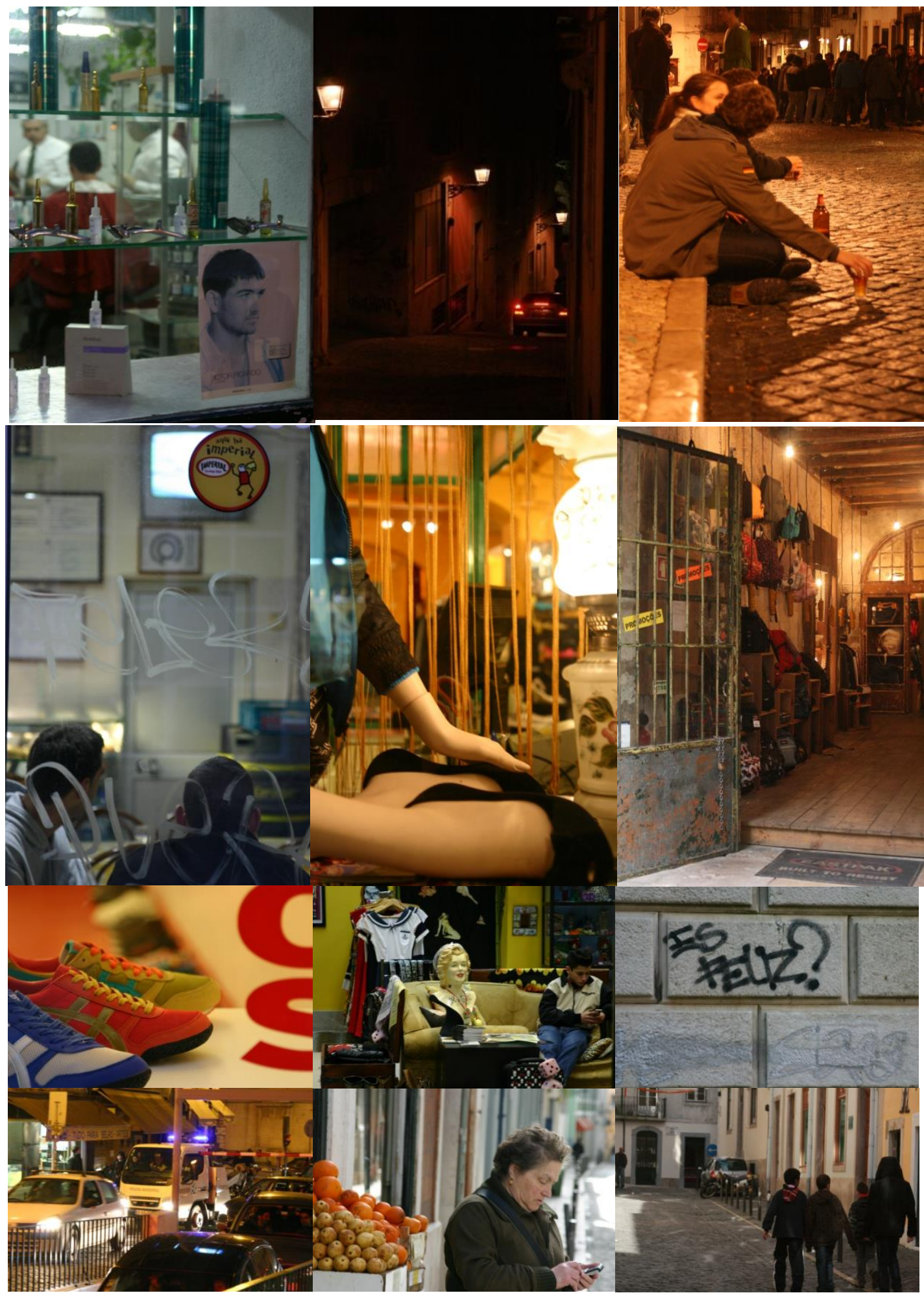
Urban design, public space and the dynamics of creative milieus:

a photographic approach to Bairro Alto (Lisboa), Gracia (Barcelona) and Vila Madalena (São Paulo)

Figure 3: Photographic approach to Gracia (I)

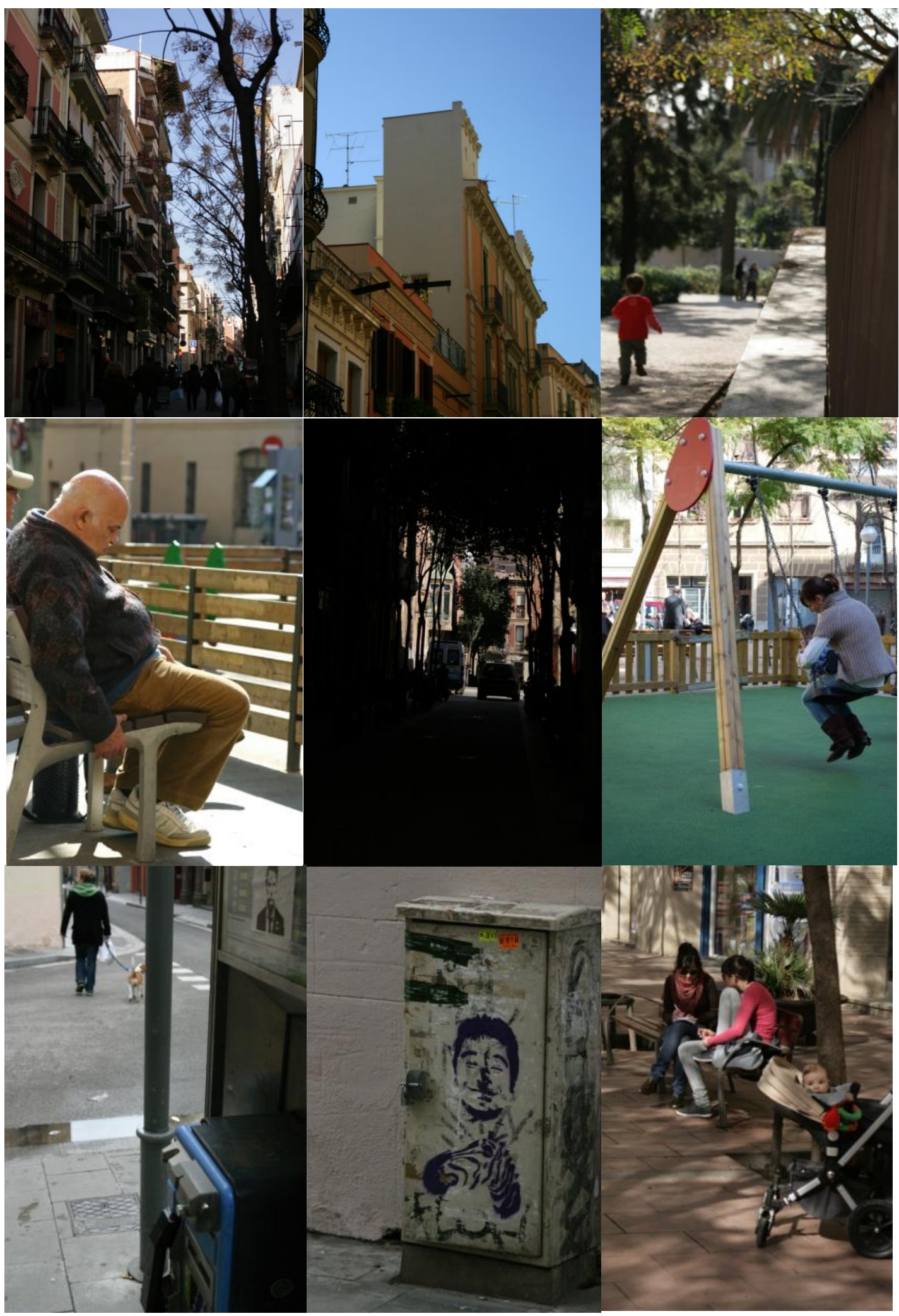


Urban design, public space and the dynamics of creative milieus:

a photographic approach to Bairro Alto (Lisboa), Gracia (Barcelona) and Vila Madalena (São Paulo)

Figure 3: Photographic approach to Gracia (II)

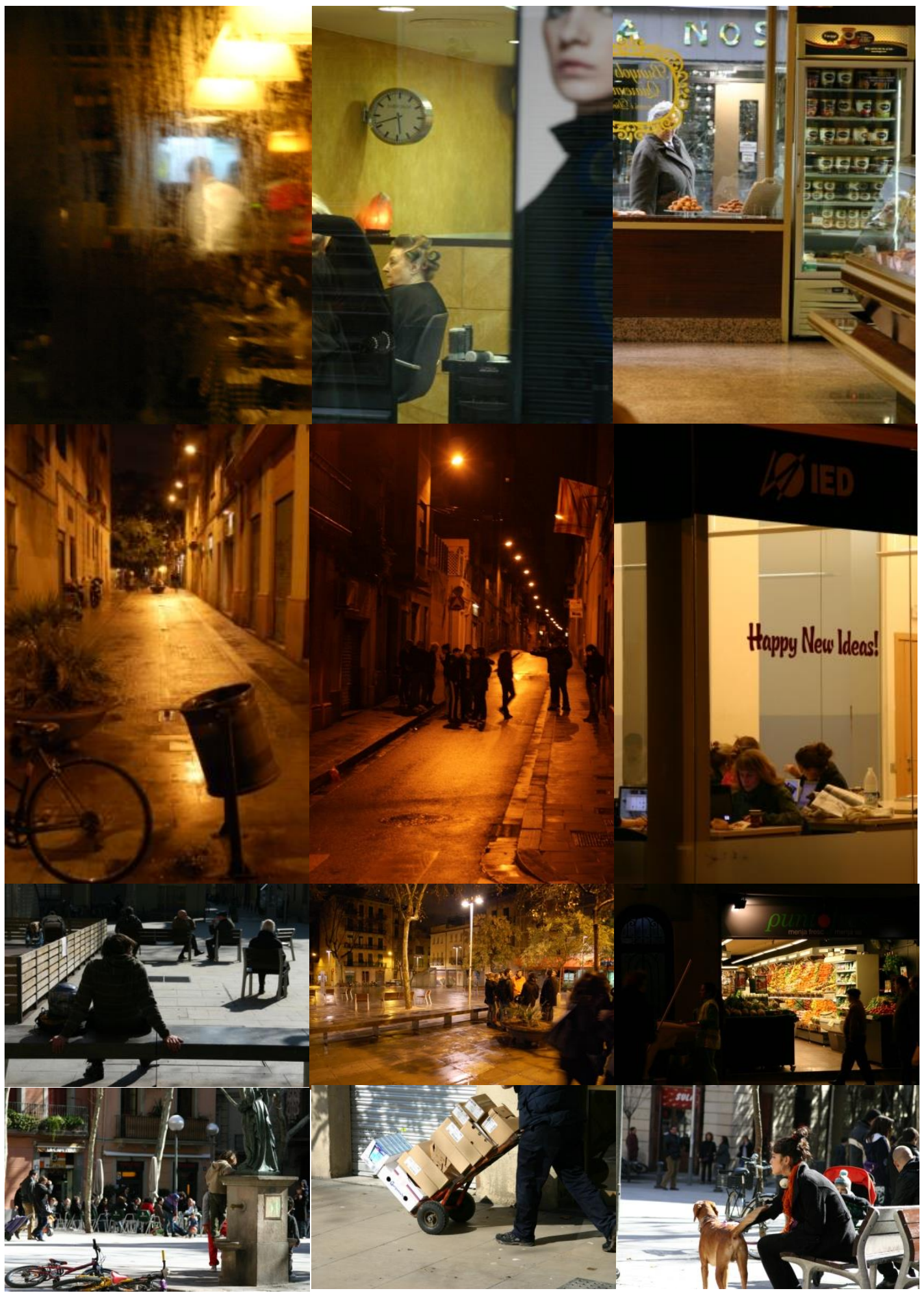


Urban design, public space and the dynamics of creative milieus:

a photographic approach to Bairro Alto (Lisboa), Gracia (Barcelona) and Vila Madalena (São Paulo)

Figure 4: Photographic approach to Vila Madalena (I)

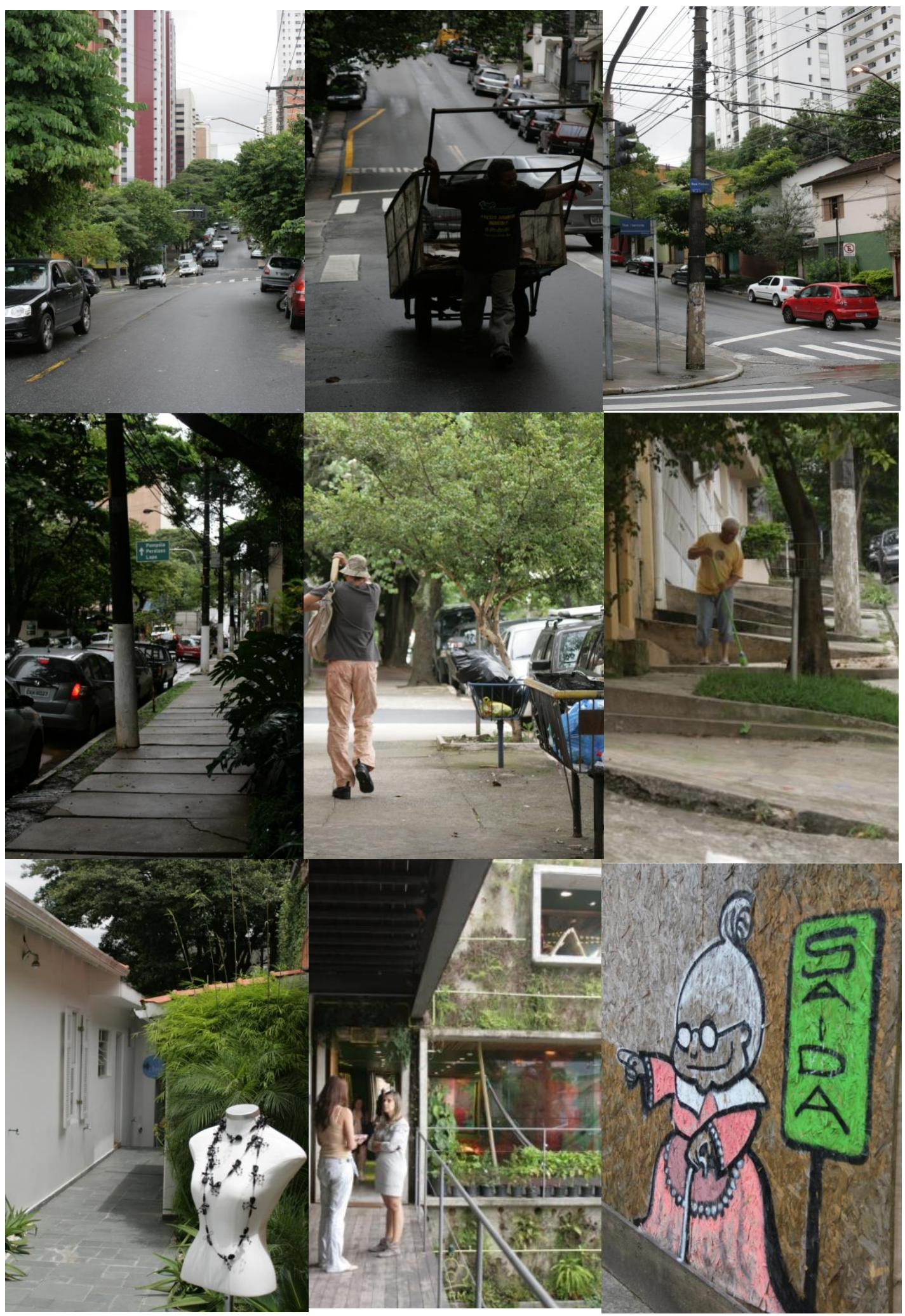


Urban design, public space and the dynamics of creative milieus:

a photographic approach to Bairro Alto (Lisboa), Gracia (Barcelona) and Vila Madalena (São Paulo)

Figure 4: Photographic approach to Vila Madalena (II)

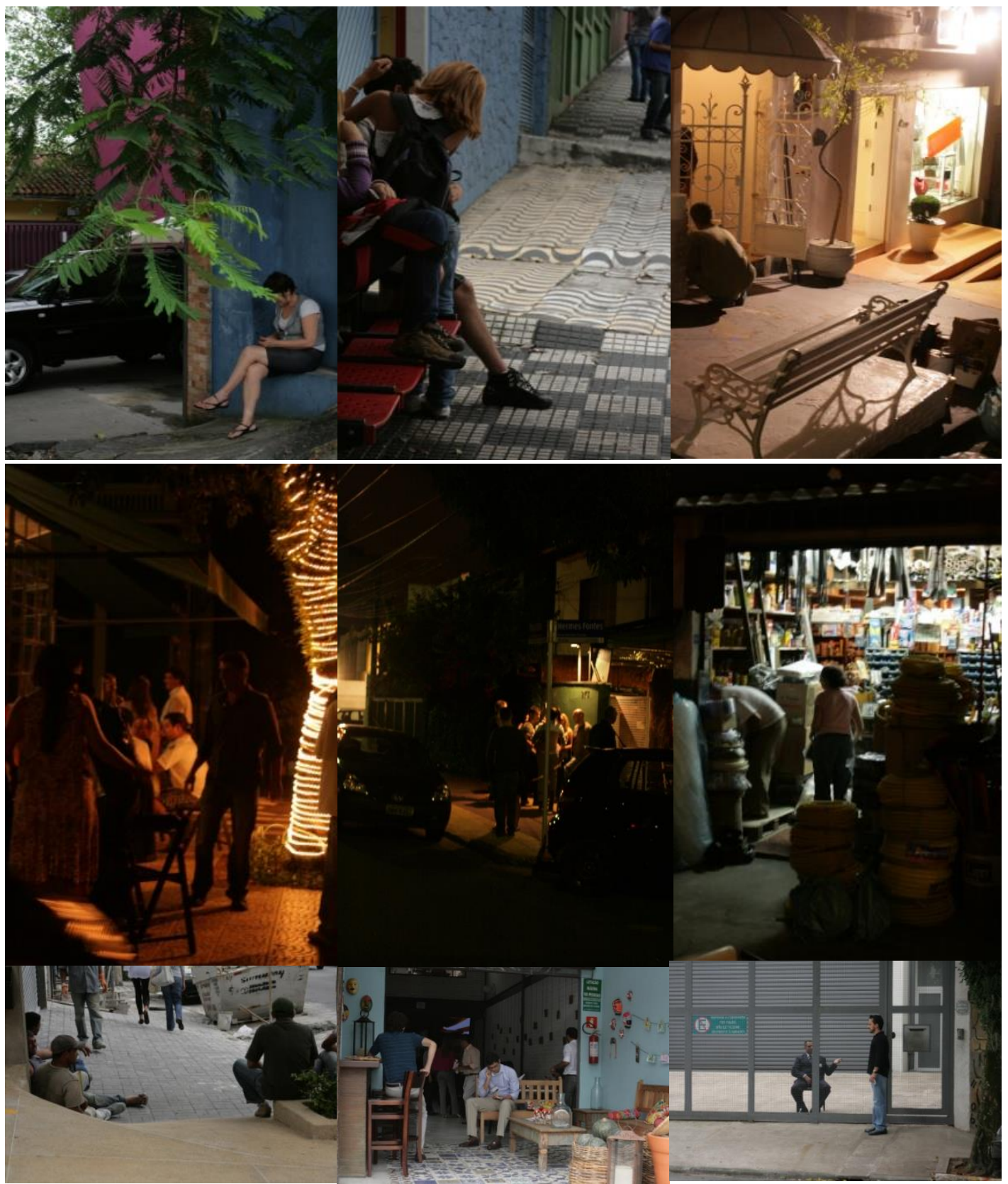




\section{URBAN MORPHOLOGY AND SUSTAINABILITY OF EACH AREA}

Urban morphology conditions the way how the spaces are lived and appropriated by the population and the way social practices take place on it. The urban design, the characteristics of the public space, and the private spaces of public use are then some of the main factors that contribute to the development and sustainability of creative dynamics.

Concerning our specific case studies, as Balula puts it, they "seem to confirm the argument of Gert-Jan Hospers (2003), when he affirms that creativity doesn't occur in vacuum, and that some urban contexts, rich in historic sediments, are the places - the physical and social supports - by excellence where creativity finds its roots." (Balula, 2010, pp. 55). All the quarters analysed are the construction of an identity that is composed throughout its centuries of history. The continuous overlapping of these layers gives at these places of the city a great functional and social diversity that sustains the development of this kind of dynamics. The essential characteristics that are in the genesis of creative dynamics (Costa et al, 2008) are more likely to develop in such conditions (Scott, 2000). Like Richard Florida notices "the urban places more attractive for the creative clusters are those that offer a diversity of experiences, and a variety of activities, and enable different lifestyles" (Florida, 2002: pp.11). This affirms undoubtedly the importance of the multifunctional urban areas against monofunctionals, as in the later the margin for interaction of different publics, styles and uses is naturally less common.

Thus, it will be interesting to give a brief framework of the historical evolution of these districts in order to understand better their current contextualization. We start the framework by the historical period of their implementation, when each area appears, in the cities of Lisbon, Barcelona and São Paulo. All the three case studies were located in the periphery of the cities on the occasion of their implantation and then they were progressively inserted in the urban core with the development and growth of the respective cities. Despite having an area of implantation and an "image of the city" that are very diverse, deriving from the different realities and historical periods in which they developed, "the three quarters have a similar morphology, being formed entirely by irregular orthogonal grid" (Balula, 2010, pp. 49). But in addition to the morphological aspects we should note that the analysis of urban morphology cannot be dissociated "of the moving parts of a city especially people and their activities, [that] are as important as the physical and real estate" (Lynch, 1960, pp.11).

The Bairro Alto was the first urban core built outside the city walls, dating from the early 16th century, being located near to one of the Lisbon "city doors" at the date. Its drawn adapts to the topography of the terrain, being the one of the three cases analyzed in which the orthogonal grid is more organic. The quarter is characterized by its narrow streets composed

DINÂMIA'CET - IUL, Centro de Estudos sobre a Mudança Socioeconómica e o Território 
majority by buildings of Pombalino period ${ }^{6}$, and despite the numerous renovations and additions, keeps essentially the historical and picturesque image of the quarter over the years. Its streets are paving by stone, the floor is irregular and away from modern mobility rules, the sidewalks are narrows our inexistent. The traffic is closed inside part of the quarter (just in recent decades), where just is possible access on the part of residents or to "charge and discharge". So the main car traffic is carried by the peripherals limits of the quarter, being just possible to cross it by Rua da Rosa that divides the quarter into two parts with different characteristics, being the Western zone mostly residential, and the Eastern zone characterized by functional diversity, and where occurs the majority of functions with social character. This is the one of the three quarters that presents a smaller area of public space ${ }^{7}$, existing only in the streets that cross the quarter, and its peripheral limits. Thus, the streets assume the function of "living room of the quarter" to the regulars who wander and chat there during daytime and for those who flock at the quarter at night, standing or sitting along the streets. The urban furniture for permanence is practically non-existent within the quarter, as well as green areas or public spaces with great dimensions (all in the outskirts of the quarter), because this this was not a concern at the time of its construction. Considered marginal, insalubrious, and poor in habitability conditions in the mid- $20^{\text {th }}$ century, it led to that projects for demolition of the quarter and the construction of a new one following news urbanisms patterns were proposed. However this did not occurred, which allowed the deployment in this area of the city of a series of activities that took advantage of the fact that it was a central and relatively low-priced economic zone to develop, such as the case of the printing cluster. Is following this logic that the contemporary creative industries begin to develop in the territory, articulating the axis Chiado - Bairro Alto, and exploring the long-term inter relation and complementarity between the institutional-daily pattern of Chiado (the side "inside" the ancient walls and institutional cultural pole of the city) and the alternative-marginal-nightlife image of the Bairro Alto area (Costa, 2007, 2009). This proficuous relation, exploring also the transgressive tradition in terms of sociability and conviviality in Bairro Alto, feed the area as the main cultural area of the city. The artistic universities placed in Bairro Alto as in Chiado increased the critical masses of who lived and attended the activities in this district, and it was in this general context that this part of the city affirmed itself over the years as the cultural and creative place for most cultural activities in Lisbon, although in recent years, this centrality has shifted progressively for

\footnotetext{
${ }^{6}$ It is included in the "Pombalino period" all the work done in the scope of the period after Lisbon 1755 earthquake, on the regia of King José I, where Sebastião de Carvalho e Melo, Marquis of Pombal was Secretary of State of the Kingdom, having promoted a wide reconstruction plan, with very distinctive character.

${ }^{7}$ Consult data in Balula, 2010, pp. 53.
} 
consumption-oriented and social and conviviality-based activities, also essential for the structuring of the creative activities cluster, but not centered on cultural creation and production.

The Gràcia was also result of a development and urban planning outside the city of Barcelona. Distanced approximately $2 \mathrm{~km}$ of the walled city, it developed as an autonomous "Pueblo", which structural characteristics still remain until today and that is reflected also in a strong sense of local identity in its population. It's encompassed in the city of Barcelona after the Cerdà ${ }^{8}$ plans. The quarter has a superior population density when compared with Bairro Alto, as happen with its implantation area and the height of the buildings. The narrow streets are usual framed by builds between 4 and 5 floors, around two more floors than the buildings of the Bairro Alto. The orthogonal grid is interrupted several times by squares, where people meet, which are the main public spaces of the quarter, equipped with plenty of urban furniture and shaded from the sun by trees. These are the scenario for the public convergence of people with a high degree of heterogeneity, assuming the role that in Bairro Alto was confined to the streets. Gràcia characterizes for being an autonomous "small city" within Barcelona. It is perfectly possible to live, to work and to access to cultural events without leaving the quarter. This mix of "needed activities", as well as both of "social" and "optional" nature (cf. Balula, 2010, pp. 50), confer to the quarter a vitality and a dynamic throughout the day, being the one of the three cases which presents a better balance between the three groups. The circulation in the quarter is organized and some streets are closed to traffic, while in others one can only circulate motor vehicles and bicycles. With these three kinds of circulation in correct hierarchy in the quarter, cars, motor vehicles and pedestrians, this doesn't reveals so much the circulations problems founded in the others quarters. The issue of parking also seems in this case somehow solved, as the car parks situated beneath the numerous squares respond to local needs, contrary to what happens in Bairro Alto as in Vila Madalena where the users take hours to park their vehicles. The sidewalks are regular and prepared for the movement of persons with reduced mobility, it's usual to found the sidewalk in the same plan the road to resolve the previous problem of the narrow streets; with this solution and the traffic controlled the major part of the time most of the streets are large sidewalks. Today, we can find a quarter accessible to any citizen. For this, the characteristics of the territory and city's town planning rules contributed a lot. The quarter doesn't have significant topographical variations; it presents a slight pending throughout the territory, however this does not feel the scale of person when compared with the others cases. The pavement of the streets and sidewalks is in most cases the same, polished stone, larger than the ones that we found in Bairro Alto, although the streets with more car traffic are paved in asphalt.

\footnotetext{
${ }^{8}$ Author of the expansion plan of the city of Barcelona out of the walls in the 19th century, giving to the city the distinctive urbanism that we know today.
} 
In Vila Madalena the aspect of street pedestrianization seems to be one of the most problematic to the quarter. In a place where there isn't an entity responsible for the organization, construction and management of the sidewalks each person is responsible for the construction and maintenance public space adjacent to its housing. Without any explicit planning rule about that or restrictions about mobility, the landowners build as they well understood. The quarter is implanted in topography of pronounced slopes which by itself would easily render its users. In addition to this factor, the hardly considered sidewalks configuration makes that it would be impossible to move around in the quarter some person with reduced mobility, although the sidewalks are large, and they are assumed as the places appropriated for the costumers who come to the zone. Contrary to what happens in other cases, in this quarter the hierarchy of streets is less marked; cars can circulate in all of them, as after all it is really an important piece to live in the quarter, contrary to what happens in the other two cases where the access to the various services is easier moving by foot or by public transport. That is one of the biggest counterpoints to those who live and go to this quarter.

Vila Madalena starts being as a small group of houses out of the city of São Paulo (such as Gracia in Barcelona). Only in beginnings of the $20^{\text {th }}$ century, with the construction of the railway line that would connect the small cluster of houses to city centre, and later in the 70's with the transfer of the Arts University of São Paulo for a near neighborhood, is that this area starts to assume the setting that we find today. Like São Paulo itself, it is characterized for being in constant mutation. It is a quarter with little more than 100 years of history. It displays an urban drawing of wide streets to automobile scale, contrary what happen with the others, which grew up before its appearance. From the beginning it was a quarter composed mostly by singlefamily homes. Today, it is in quite advanced state of gentrification and many of the singlefamily building that composed (and symbolized) the quarter has been replaced by buildings with more than ten floors. These urban changes are disfiguring, in physical terms, the "old" artist quarter (that itself is a gentrification of the precedent blue-collar workers neighborhood, although in that previous case the change did not reflected too much in the buildings characteristics). As Samuel Dias states, "in São Paulo, it was built up on top instead of building next to" (Dias, 2010, pp. 20), and we can say also at high speed, due to the economic and demographic expansion, that progressively get new areas of the city. The municipal master plan allows the replacement of the old builds by others with completely different characteristics, contrary to what happens in the Spanish and Portuguese case, where the regulations don't allow this kind of modification in the characteristics of existing edification, with more restrictions in the Portuguese case and a more flexible paradigm in the Spanish case. These kinds of alterations in edification typologies of Vila Madalena are changing the intrinsic characteristics of the district, due to the changes in uses and in the population that these restructurings generate. The 
old buildings are mostly replaced by private condominiums that not only involve lesser levels of public space appropriation as also do not guarantee the same mix of activities that was present in the old structure of the quarter. That have being conducting to a certain lost of vitality, contrary to what seems to happen in both the other districts, where the strategy has been keeping mixed uses in the buildings and multifunctional areas, in spite of the use conflicts that this can also generate.

The private spaces of public use also diverge between the different cases. Different uses and spatial typologies affect the way how the public space adjacent is appropriated, depending on the characteristics of the activity and how they develop, and these diverse situations generate different appropriations of public space by breaking the boundaries between private space of public use and public space, originating in some cases (noticeable the ones related to conviviality or some artistic interventions on these spaces) considerable use conflicts between users and residents. When economic and cultural activities leave private space of public use and implant themselves in the public space, they became the center and target of polemic and divergent opinions, typical in this kind of quarters, marked by the heterogeneity of resident population and regular or occasional users, which make themselves evident, at different rhythms, throughout the day. This kind of dynamics are one of the most visible "brand images" of these kinds of districts, where it is not unusual to find many of the public spaces regularly occupied by multiple passersby, who fill the streets and sidewalks in Bairro Alto, the squares in Gràcia and the large sidewalks of Vila Madalena, making part of the urban landscape of these places, and being the main actors on the stage where most of interpersonal contacts take place.

In addition to the physical and material appropriation, it is important to mention how private spaces of public use show themselves and make themselves evident throughout public space, assuming a great importance in those places. The images that can be perceived through the shop windows, the light that is reflected in public spaces, the sounds and the smells, among many other, are all fundamental elements that contribute to the identity of the these places. The Bairro Alto and the Gràcia with its mixed-use buildings and the commerce along the streets turn out to be an element of great attractiveness, "enriching" the experience of walking and wandering through each of these quarters. On the contrary, in Vila Madalena, being a quarter marked by more monofunctional buildings, it can become a more tedious or at least less surprising experience, as activities are a little more divided between the different territories. This can lead to lower conflicts of use in this place, when compared with the rest of the cases; however, it can represent also a certain loss of one of the great virtues of these territories, that is to enable the confrontation of different people and uses, that by their diversity enriches the city and the lives of who uses it. 
This kind of districts, as already explained, has at its disposal a diverse range of qualities and cultural offers that make them most desirable in the city. Joining to this factor its centrality, this leads to that they can mobilize a strong demand, even in central functions of high level, with larger demand thresholds. However, it is not always easy to an old quarter to continue offering the best commercial typologies, residential conditions or access to public facilities, while technological evolution, city spread and people's expectancies and ways of living constantly evolve. The three districts are all good examples of this, with difficulties in accompanying these structural changes, at least for some markets (mostly the more generalist and mass-based ones, both at residential and commercial levels). However this can be one of the main factors that contribute to the sustainability of the activities that keep in the quarter and to the dynamics of the area as creative system (Costa, 2012, 2013, Costa et al, 2010). If the commercial typologies would be more versatile, like the ones found on a shopping mall or on other commercial centers of the same city, they would be quickly occupied by other economic activities, with more financial capacity to pay that place, as soon as they become more mainstream in people's practices and in people's representations. That would rapidly conduct to the decrease in the specificity of the offer of products found in this type of quarter, with the subsequent consequences in the field of the symbolic and the representations, with greater impact in the cultural related activities (cf. Costa, 2012). By the same token, if the housing stock would be all equal, this would encourage a more egalitarian city, with more similar rhythms and life styles, and daily lives, turning these areas into a less attractive kind of city for whom looks for it today, and to a place that would not be lived at all the different times of the day, as it happens in many suburbs of the same cities.

Summing up, as can be seen for all that is said in the precedent paragraphs, w3 can assume that the characteristics of urban design, specific place morphologies and typologies are determinant for the attractiveness of creative activities and for the appropriation of these areas by sustainable dynamics on the cultural and creative sector. That is a conclusion that we could draw from the empirical analysis of the 3 quarters that were studied in this project. As seen before (Costa et al, 2010; Costa, 2009, 2012, 2013) these are not sufficient conditions for the development of those dynamics, and moreover, for their sustainability through time. But they are important conditions for the development of these systems, for the functioning of their governance systems, and for their sustainability. The gentrification processes in all of these quarters would be far more extent now if there wasn't some of the strong morphological (and urban planned-based) conditions that regulate their development. For instance, in the case of Bairro Alto (where planning conditionings are stronger and these effects are mostly noticed) if we would not have those kinds of streets, dwelling conditions or traffic structure, for instance the selective gentrification process that took place, privileging creative and artistic oriented 
lifestyles, would be far gone. At the moment that houses or shops could be bigger, with different typologies, that they could have a lift, that the car could be parked near the door, that the multiple conflicts in the public space decrease, that the diversity of the people present in that public space decrease, probably other social segments would take the place of the artists and the creative people in this part of the city, as recurrently happened in other cities before. Both by the effect in land prices and the effect in the symbolic mainstreaming of the quarter, the artists give place to the ones that have the power to keep in the area. And on that moment, the sustainability of the area as creative system is clearly challenged.

\section{CONCLUDING NOTE}

This paper aimed to discuss the relation between urban design and the creative dynamics in cultural districts. Urban morphology clearly takes a relevant place in this relation. Departing from a discussion on the boundaries of public spaces and their relevance for the creative dynamics (through the conviviality and sociability they promote, which is a key feature to creative dynamics - cf Scott, 2000 - and to the reputation and gatekeeping mechanism essential to cultural activities development - cf. Costa, 2012 -), it was discussed how the characteristics of urban design, specific place morphologies and typologies are determinant for the attractiveness of creative activities and for the appropriation of these areas. The uses, practices and symbolic representations that take place in those areas, as well as the use conflicts that arise on those multiple arenas (e.g. between nightlife users and residents that want to sleep, between grafitters and property owners, between street performers and residents, between traditional activities and newcomers,...), are essential for the balances on the evolution of these territorial systems, and often are key-factors associated to their governance systems. As consequence of this, these morphological aspects should be also discussed as central at the light of the main challenges to the sustainability of each of these areas, when we think of them as "vital" and "creative" centers in their cities.

Not being our intention to discuss here in more detail the governance of these systems (see Costa, 2012, 2013), or even the general regulation and governance of the public spaces of these areas (cf. Costa et al, 2010, Costa, 2012), we just want to sum up some ideas about the particular issues on the governance of these systems that are specifically related to urban morphology and to the design of public spaces.

As we have seen, the situation is very different in each of the 3 cases. While in São Paulo the action of the diverse stakeholders is much free than in the other cases, and the planning procedures are much softer, in the Lisbon case we have the opposite situation, with 
strict regulation, about what can be done (or not) in private and public spaces (although many times not fully effective...). In the Barcelona case, with an intermediate situation in terms of policy-orientations and planning practices, other factors, such as associative tradition and social composition of the district, play a major role in the governance of the area, and the results are many times more efficient than in Lisbon.

Facing several common problems (infrastructure congestion, use conflicts related to different interest on public space utilization, and so on), local stakeholders negotiate diverse situations and policies through time: e.g., closing streets to traffic or not; investing in public facilities on public space; controlling building permits or not; limiting nightlife schedules mechanisms; managing permits and licensing for the several kinds of economic and cultural activities functioning conditions; allowing or nor more deviant behaviors towards social norms, and being more or less tolerance regarding diversity manifestations in public places; being more strict or less strict concerning the accomplishment of all legislative and security criteria for all activities; approving the construction of private managed condominiums in the area; managing commercial or artistic use of public squares and streets for events; managing permittivity to wall appropriation, for artistic or communicational purposes; managing of urban hygiene problems due to the pressings over these systems; and so on. Some of these actions can be translated in common procedures in terms of urban planning in the 3 cities (concerning traffic regulation, parking, noise, schedules,...), but other represent very diverse approaches to planning, some of them due to the diversity of the degree of those problems and to the diversity of planning frameworks (urban licensing, hygiene, security).

Two main ideas result from this diversity. One is that we need to understand that these areas are naturally marked by conflicts between agents with diversified interests. Such conflicts may be minimized in order to promote well-being and quality of life in the area, to their residents, activities and users, and this is a role that public authorities must try to accomplish. But sometimes that conflict can be also important to maintain the diversity of this site, to be possible to that system to sustain, to that place to renew and reinvent itself, and to keep always its vitality. Activities rarely maintain over long periods of time in the same place, which increases their rotation, and makes those places living organisms, with a local dynamic themselves, distinctive in their city. Regulation must go through an attempt to leave these spaces living by themselves, giving room for happen different things, differently to what happens in the rest of the city, giving space for greater freedom. By their own nature, creative activities are anti-institutionalization, and more open planning instruments, dealing with creative solicitations from society, will be certainly more efficient that too rigid ones. 
The other idea in terms of the concluding policy-making guidelines that are drawn out from the analysis is that we can never forget the diversity of this situations and non-transferability of policy instruments or policy agendas. As it is also clearly demonstrated in these 3 cases, even with many similarities in this 3 cultural districts and the challenges that all of them are going through, with their transformation and gentrification risks, the fact is that the sustainability of each of these territorial systems is dependent of the specific actors and specific processes that take place in each situation. Policy responsible authorities have to understand the specific governance mechanisms that are the driver of each system (that are very diverse in each of these 3 cases), and then act specifically considering what are the real possibilities, instruments and objectives that they can manage and negotiate with all the other involved stakeholders. It is easy to design and set up a "creative city" strategy in each of these districts or even in other part of these cities. The difficult is to do that without destroying all the mechanisms that were underneath the creative dynamics that previously existed in those places, and without putting at risk the mechanisms that enable the sustainability of that system as a creative one. And for that, amongst many other things, we need to fully understand the morphology of the area, the urban design, and the way it interacts with the social and cultural practices that took place in it, and the interaction with the symbolic system that is inherent to it. 


\section{REFERENCES}

ARANTES, A.,1997. A guerra dos lugares: fronteiras simbólicas e liminaridade no espaço urbano de São Paulo. In Fortuna, Carlos (org.), Cidade, Cultura e Globalização - Ensaios de Sociologia, Oeiras, Celta, pp. 259-270.

BALULA, L., 2010. Espaço público e criatividade urbana: A dinâmica dos lugares em três bairros culturais. Cidades, Comunidades e Territórios, n²0/21, Dezembro 2010, pp. 43-58.

CAMAGNI, R., Maillat, D., Matteacciolli, A. (Eds.), 2004. Ressources naturelles et culturelles, milieux et développement local. Neuchatel: EDES.

CAMPOS, R., A. Mubi Brighenti, L. Spinelli, 2011. Uma cidade de imagens: Produções e consumos visuais em meios urbanos. Lisboa, Editora Mundos Sociais.

CAVES, R., 2002. Creative Industries: Contracts between Art and Commerce. Cambridge /London: Harvard University Press.

COOKE, P. and L. Lazzeretti (org.), 2007. Creative cities, cultural clusters and local development. Cheltenham: Edward Elgar.

COSTA, P., 2007. A cultura em Lisboa: competitividade e desenvolvimento territorial, Lisboa: Imprensa de Ciências Sociais.

COSTA, P., 2009. Bairro Alto - Chiado: Efeitos de meio e desenvolvimento sustentável de um bairro cultural, Lisboa: Câmara Municipal de Lisboa - DPPC.

COSTA, P., 2012. "Gatekeeping processes, reputation building and creative milieus: evidence from case studies in Lisboa, Barcelona and São Paulo", in Lazzeretti, L (Ed.), Creative industries and innovation in Europe: Concepts, measures and comparatives case studies", Routledge, pp286-306.

COSTA, P. (org.), 2013 (forthcoming). Criatividade e Vitalidade Urbana. Lisboa, Barcelona e São Paulo, em publicação. 
COSTA, P.; Latoeira, C.; and Lopes, R., 2010. Apropriação, conflitos de uso e produção do espaço público em 3 bairros criativos: uma abordagem fotográfica ao Bairro Alto, Gracia e Vila Madalena. (Manuscrito dos Autores).

COSTA, P; M. Magalhães, B. Vasconcelos, e G. Sugahara (2008), On 'Creative Cities' governance models: a comparative approach. The Service Industries Journal, Vol. 28, n⿳3 3-4, April-May 2008, pp. 393-413.

COSTA, P., B. Vasconcelos and G. Sugahara, 2011. "The urban milieu and the genesis of creativity in cultural activities: An introductory framework for the analysis of urban creative dynamics", Cidades, Comunidades e Territórios, № 22, Dezembro 2011, pp. 3-21.

COSTA, P., Lopes, R., 2011a. "Padrões locativos intrametropolitanos do cluster da cultura: a territorialidade das actividades culturais em Lisboa, Barcelona e São Paulo”, REDIGE - Revista de Design, Inovação e Gestão Estratégica, Vol. 2, n. 02, 2011, pp. 196-244.

CULLEN, G., 1983 (1971). Paisagem Urbana. Edições 70, Lda.

DIAS, S., 2010. Um percurso histórico por 3 bairros criativos: a identidade e a formação morfológica urbana. (Manuscrito do Autor).

EVANS, G., 2009. Creative cities, creative spaces and urban policy in Urban Studies 46. 10031040.

FLEW, T and S. Cunningham., 2010, Creative Industries after the First Decade of Debate. The information Society, 26: 113-123.

FLORIDA, R., 2002. The rise of the creative class. New York: Basic Books.

HALL, P., 2000. Creative cities and economic development. In Urban Studies, 37 (4), 639-649.

HEALEY, P., 2004. Creativity and urban governance. DISP, 158, 11-20.

HOSPERS, Gert-Jan., 2003. Creative cities: breending places in knowledge economy. Technology, \& Policy, 16(3), pp.143-62. 
JACOBS, J., 1989 (1961). The Death and life of American Cities. New York: Vintage Books, a Division Random House.

KUNZMANN, K., 2004. An Agenda for Creative Governance in City Regions. DISP, 158, 510.

LANDRY, C., 2000. The Creative City: a toolkit for urban innovators. London: Comedia /Earthscan.

LYNCH, K., 1982 (1960). A imagem da cidade, Lisboa, Edições 70.

MARKUSEN, A., 2006. "Urban development and the Politics of a Creative Class: Evidence from the Study of Artists. Environment and Planning A, Vol. 38, No. 10:1921-1940.

O'CONNOR, J., Wynne, D. (ed.)., 1996. From the Margins to the Centre: Cultural production and consumption in the post-industrial city. Aldershot: Arena.

SCOTT, A. J., 2000. The Cultural Economy of Cities. New Delhi, London- Thousand Oaks: Sage.

A. J., 2006. Creative Cities: Conceptual issues and Policy Questions. Journal of Urban Affairs, Volume 28, Number 1, pp. 1-17.

SEIXAS, J. e Costa, P., 2010. Criatividade e governança na cidade contemporânea: a conjugação de dois conceitos poliédricos e complementares. Cidades, Comunidades e Territórios, № 20-21, Dezembro 2010, pp. 27-41.

SOLÀ MORALES, I. de., 2002. Territórios. Barcelona, Editorial Gustavo Gili.

SONTAG, S., 2008 (1977). On Photography. Londres; Penguin Modern Classics. 